\title{
Cyber Abuse Behaviour in Young Adults : Revenge Porn and how the Bournemouth University Community can learn from the issue.
}

\author{
Norbert Rogers \\ Faculty of Science and Technology - \\ Department of Computing and \\ Informatics \\ Bournemouth University \\ Bournemouth, United Kingdom \\ s5324485@bournemouth.ac.uk \\ https://orcid.org/0000-0002-1652-0305 \\ https://osf.io/6wb97/
}

\begin{abstract}
This paper analyses the impact that victims of cyber extortion face in particularly with revenge pornography. It points out legislation available for remedial action in civil cases such as sextortion. The paper is written to help safeguard university students from online harassment and points out the channels available for reporting incidences of revenge porn.
\end{abstract}

Keywords-Revenge Porn, Sextortion, Cyber Abuse, Cyberstalking, Cyber Harassment

\section{INTRODUCTION}

The Daily Mail in 2015 reported a shutdown of a fraternity called Kappa Delta Rho, at Pennsylvania State University in the United States of America, for allegedly posting demeaning nude photos of inebriated females on a private Facebook page [1].

In another event, a 25-year-old man was arrested for allegedly circulating female nude photos of women, after accessing their social media accounts, through which he infiltrated by using their weak university email accounts [2].

Both incidences above relate to cyber abuse. Cyber abuse is a general term that describes a person's online behaviour involving cyber harassment and cyberstalking and is an ongoing social problem today [3]. Revenge porn and sextortion, are digital crimes of sexual exploitation in nature. It is a phenomenon where an attacker threatens a victim with exposure of explicit photos or videos that are of sexual nature, without their permission [4]. When this happens, victims have no remedy but to be at the mercy of their aggressors. This form of cyber blackmail in young women is becoming a common crime especially among users with limited technical know-how.

The aim of this study is to investigate the problems that victims of cyber abuse face. This will focus particularly on young adults who experience cyber extortion in the form of revenge porn or sextortion in higher institutions of learning. This research will explore various university policies in addition to public policy and come up with a solution to help safeguard and foster a secure environment for students at Bournemouth University.
This paper will be conducted through analysis of literature and by mixed-method research.

\section{StAtistics AND REVIEW}

To highlight the weight of this problem, research was conducted at the Crimes against Children Research Centre from the University of Hampshire in 2016 in the United States of America. This research included a survey of 1631 young adults who were victims of sextortion. The findings established that $45 \%$ of the victims experienced some form of threat from offenders or were even harmed [5].

In the United Kingdom, the Office for National Statistics conducted statistical analysis for cybercrimes in the year 2021. The data was collected through police reports recorded in England and Wales. It was established that cybercrimes relating to harassment and stalking amounted to $22 \%$ of total offenses flagged as online crimes that year. In addition, 59\% of the total crimes reported were related to obscene publications, $44 \%$ pointing to blackmail, and $12 \%$ associated with child sexual offenses [6].

Ditch the Label, a charity that advocates for anti-bullying and promoting equity among the youth conducted a study of 2732 adolescents to age 25 . The research found that $37 \%$ of the young adults admitted to sending naked photos of themselves online, making them more likely to fall prey to revenge porn syndicates [7].

In the year 2016, a consortium of 140 universities in the United Kingdom called Universities UK, came together in partnership to fund a project in response to cyber harassment reports. The reports came from several female university students of multiple institutions of higher learning and were announced by the National Union of Students. As a result, this led to the development of some guidance to help with combating cyber-harassment and help promote students' cyber welfare [7].

However, it has been observed that there are some limitations in quantifying the actual incidence rates mainly due to some students not being aware of various reporting channels resulting in low numbers of reports being recorded [7]. 


\section{INVESTIGATIVE AREA}

Revenge pornography is the exposure of a person's pictures or videos to the public without the prior consent of the individual affected. Women are the most common victims of this form of abuse with the motive being to harm, humiliate intimidate and extort the victims [7].

\section{Victim Impact Analysis}

A research group "Ditch the Label" found that of the negatively impacted victims, $26 \%$ of young adults that have had their naked photos exposed to the public without permission developed suicidal thoughts. $12 \%$ of victims attempted to kill themselves with $32 \%$ losing selfconfidence. Other observations included victims dropping out of education systems, isolation from friends and family, having traumatizing memories of the incidents, developing fear and anxiety, development of antisocial behavior, drug and alcohol abuse dependency [7].

In another research, conducted by Amnesty International in 2017, surrounding the psychological impact of victims of cyber abuse, it was found that more than $55 \%$ of affected women experienced stress, became insomniac which was accompanied by the inability to concentrate for long periods of time [8]

In 2018, Jane Wakefield from the British Broadcasting Corporation reported a story of a Musician, Youtuber, and now turned revenge porn activist, Ms. Chrissy Chambers. Ms. Chambers became a victim of revenge pornography after a fan of hers discovered her personal private video, which had been uploaded to an adult website. It is believed that Chrissy's ex-boyfriend had been circulating the explicit video and led to a four-year legal battle between Ms. Chambers's lawyers and her ex-boyfriend. As a result, Ms. Chambers turned to alcohol dependency at the age of only 23, had depression, anxiety and now has post-traumatic stress disorder [9].

\section{Perpetrators}

It is inconclusive as to the type of people that are driven to engage in acts of cyber sextortion. In a research paper by the UK Council for Internet Safety on Adult Online Hate, of the perpetrators accused of online harassment, 34\% were strangers to the victims, and $32 \%$ of cases involved multiple people [10].

In a Liverpool Magistrate Court case involving a jealous ex-lover, a 53-year-old man Mr. David Jones was charged for disclosing private sexual photographs of Ms. Nicola Collin without permission and uploading them to a porn website. Under section 33 of the Criminal Justice and Courts Act 2015, Mr. Jones was sentenced to 3 months in prison [11].

However, in a bizarre statement by Mr. Jones, he claimed that he published obscene photos to rekindle the relationship with his ex-lover [11].

In another case, a 44-year-old man of Greater Manchester, confessed to the police of publishing an exlover's naked photos on Facebook for 4 hours, in the hope to put some closure on their relationship. He claimed he was unaware that it was a criminal offense and was later sentenced to 4 months in prison [12].

\section{MITIGATING RISK}

It is advisable for university students to learn more about security features that pieces of technology have to offer in order to stay safe online, especially for social media.

Universities UK together with industry experts developed guidance to help universities tackle problems with online harassment and enhance their practices and policies. The developed guidelines seek to maintain students online welfare and ensure the following: [13]

- Students participate, engage in the responsible use of technology programs, assessments of awareness programs, promoting peer-to-peer programs and networks for supporting students to prevent cyber harassment [13].

- Universities to be proactively responsible for safeguarding students against cyber-harassment and offer support for incidences reported [13].

- Universities to provide information to students about what constitutes cyber harassment and how to protect themselves against multiple forms of cyber harassment including engagement with former victims [13].

- Universities to develop cyber policies, codes of conduct, and a list of the disciplinary procedure followed when a user is found to be in misconduct of university policies [13].

\section{Lessons from other Universities}

The University of Suffolk introduced a program to improve online safety awareness content by partnering with external speakers and experts. They also have a process that constantly reviews universities' policies and runs programs to raise cyber safety awareness campaigns through social media, workshops, and leaflets [14].

The Anglia Ruskin University has an online platform called 'Shared Practice Area' that facilitates its members with a shared environment that encourages learning from each other and have shared good practices to help fight cyber harassment, sexual violence, and discrimination [14].

\section{Legislation}

There are several Acts of parliament in the United Kingdom which protect victims of revenge porn and cyber extortion both in England and Wales. Some of these include:

- The Criminal Justice and Courts Act 2015: Section 33. The Act declares that it is a criminal offense to disclose a private sexual photograph without the owner's consent including disclosing such content as being a photo or film with intent to cause distress [15].

- Domestic Abuse Act 2021. The Act states that it is criminal to threaten disclosure of intimate images or videos with the intent to cause distress [16].

- Malicious Communications Act 1988. The Act declares that it is an offense to send threatening letters or offensive messages with the intent of causing extortion. This suggests sending messages or emails 
that a perpetrator might use to try and extort a victim [17].

- Voyeurism (Offences) Act 2019. The Act states that it's an offense to sexually record someone without their consent for sexual gratification which includes up skirting [18].

- Stalking Protection Act 2019, The Act makes a provision for orders to protect persons from risks associated with stalking and for connected related offenses [19].

\section{What Bournemouth University is Doing}

From time to time, Bournemouth university runs Cyber Security Month where tips are shared about how to keep students' personal information and devices safe and secure. This includes information such as password protection, backing up work, inspecting malicious links, reporting unwanted mail, awareness of social engineering attacks, encrypting files, and how to report concerns about IT Security at BU [20],[21].

\section{Victims Remedy}

\section{National Fraud Intelligence Bureau}

The National Fraud Intelligence Bureau together with the National policing lead for economic crime has platform actionfraud.police.uk, which should be used to report cybercrime. Reports are analyzed by experts then shared with law enforcement agencies for further investigations which can lead to the prosecution of perpetrators. Reports can be made by individuals, charities, corporations, and even by the police [22].

\section{Suzy Lamplugh Trust}

They run the national stalking helpline together with London stalking support service for help with counseling, to reduce the psychological impact of stalking. The support service helps the victims to heal from the inside from posttraumatic stress and depression as a result of sextortion [23].

\section{Cyber Civil Rights}

The cyber civil rights realized how traumatic it can be for users to see their intimate images online without consent. So together with tech and social media companies, they have compiled a comprehensive guide online to help victims of revenge porn, remove their intimate images and pictures online. This includes removal from websites including Facebook, Instagram, Google, Microsoft, Yahoo, Reddit, Twitter, and Snapchat. The organization also intervenes in cases to defend victims of image-based sexual abuse [24].

\section{Revenge Porn Helpline}

The hotline was established in 2005 and runs a service supporting adults in the United Kingdom being affected by abuse in form of revenge porn or sextortion. They assist with guidance and support for the removal of adult theme content shared illegally online. They are open Mondays to Fridays and can also be contacted using an anonymous contact form [25].

\section{Security Awareness}

Users need to keep abreast with modern online security trends to safeguard themselves. The National Cyber Security Center come up with six actions that can be followed in order to improve cyber security. This includes creating strong and separate email passwords, enabling multifactor authentication, saving passwords in browsers instead of in clear text files, running updates on devices, and backing up data.

\section{Recommendation}

Students at Bournemouth will have to be selective in the information they share with other users online. Users need to avoid accepting friends' requests from people that are not known, block people who seem to misrepresent themselves, use encryption software for sensitive information including videos and pictures, not click on unknown hyperlinks, and report suspicious behavior to the Bournemouth University IT Service Desk. The University could run a monthly forum in collaboration with regional institutions to address cyber security concerns and share lessons learned from past threats.

Future work needs to be done in the research area so that we assess the University's IT policies and procedures, which should lead to the development of an intranet portal for internal information sharing.

\section{CONCLUSION}

In this paper, we discussed the issues of revenge porn, its impact on society, and point out how best to safeguard university students against sextortion. The paper also discusses a few remedies that can be considered when a user falls victim to revenge porn. It finishes off by recommending a few approaches that the Bournemouth University community can adopt and how policy could be improved. Ideally, the best way to avoid revenge porn for starters is not to take any adult-themed recordings or pictures of any sort. This will result in the market decline of such content. 


\section{REFERENCES}

[1] Associated Press, Robinson.J, "Controversial fraternity shut down for THREE YEARS after members posted pictures of brutal hazing, drugs and naked women on secret Facebook page",May 27,2015. Accessed on: Nov 05, 2021 [Online]. Available From: https://www.dailymail.co.uk/news/article-3098421/Penn-State-fratlinked-nude-photos-sidelined-3-years.html

[2] U.S. Department of Justice, "Man Pleads Guilty to Stealing Nude Photos of Dozens of Victims",Feb 9, 2021. Accessed on: Nov 05, 2021 [Online]. Available From: https://www.justice.gov/opa/pr/manpleads-guilty-stealing-nude-photos-dozens-victims .

[3] Zarina I. Vakhitova, Clair L. Alston-Knox, Ellen Reeves \& Rob I. Mawby, "Explaining Victim Impact from Cyber Abuse: An Exploratory Mixed Methods Analysis",June 09, 2021.Accessed on: Nov 05, 2021 [online]. Available: https://www.tandfonline.com/doi/pdf/10.1080/01639625.2021.192155 $\underline{\text { 8? needAccess }=\text { true }}$

[4] Patchin.J Hinduja.S, "Sextortion Among Adolescents: Results From a National Survey of U.S. Youth" Sept 28,2018. Accessed on: Nov 05, 2021[Online].AvailableFrom: https://journals.sagepub.com/doi/full/10.1177/1079063218800469

[5] Greenberg.P, "Fighting Revenge Porn and 'Sextortion'" Aug,2019. Accessed on: Nov 05, 2021 [Online]. Available From https://www.ncsl.org/research/telecommunications-and-informationtechnology/fighting-revenge-porn-and-sextortion.aspx

[6] Stripe.N, "Crime in England and Wales: Other related tables" Nov,2021. Accessed on: Nov 08, 2021 [Online]. Available From https://www.ons.gov.uk/file?uri=\%2fpeoplepopulationandcommunity $\% 2$ fcrimeandjustice $\% 2$ fdatasets $\% 2$ fcrimeinenglandandwalesotherrela tedtables\%2fyearendingjune2021/otherrelatedjun21final.xlsx

[7] UniversitiesUK, "Tackling Online Harassement and promoting online welfare" Aug,2021 .Accessed on: Nov 08, 2021 [Online]. Available From:

https://www.universitiesuk.ac.uk/sites/default/files/uploads/Reports/ta ckling-online-harassment-literature-review.pdf

[8] Amnesty International, "Amnesty reveals alarming impact of online abuse against women", Nov,2017. Accessed on: Nov 08, 2021 [Online]. Available From: https://www.amnesty.org/en/latest/pressrelease/2017/11/amnesty-reveals-alarming-impact-of-online-abuseagainst-women/

[9] Chrissy Chambers: Revenge porn almost killed me",Jan,2018. Accessed on: Nov 08, 2021 [Online]. Available From: https://www.bbc.co.uk/news/technology-42733034

[10] Davisdon.J, Livingstone.S, Jenkins.S, Gekoski.A, Choak.C, Ike.T, Philips.K, "Adults Online Hate, Harassment and Abuse". June,2019. Accessed on: Nov 08, 2021 [Online]. Available From: https://assets.publishing.service.gov.uk/government/uploads/system/u ploads/attachment_data/file/811450/Adult_Online_Harms_Report_20 19.pdf

[11] Humphries.J, "Wallasey man who posted revenge porn online jailed in first Merseyside case", Aug,2015. Accessed on: Nov 08, 2021 [Online].AvailableFrom:

https://www.liverpoolecho.co.uk/news/liverpool-news/wallasey-manwho-posted-revenge-9881650

[12] Abbit.B, "Jealous ex jailed for posting revenge porn on Facebook to 'humiliate' former girlfriend", Aug,2015.Accessed on: Nov 08, 2021 [Online].AvailableFrom:

https://www.manchestereveningnews.co.uk/news/greater-manchesternews/jealous-ex-jailed-posting-revenge-9851218
[13] UniversitiesUK, "Tackling Online Harassment and Promoting Online Welfare", Aug,2019. Accessed on: Nov 08, 2021 [Online]. Available From:

https://www.universitiesuk.ac.uk/sites/default/files/field/downloads/2 021-07/tackling-online-harassment.pdf

[14] Universities UK, "Tackling Online Harassment and Promoting Online Welfare, Case Studies", Aug,2019. Accessed on: Nov 08, 2021 [Online].AvailableFrom:

https://www.universitiesuk.ac.uk/sites/default/files/uploads/Reports/ta ckling-online-harassment-case-studies.pdf

[15] The National Archives, "Criminal Justice and Courts Act 2015: Section 33", 2015.Accessed on: Nov 08, 2021 [Online]. Available From: https://www.legislation.gov.uk/ukpga/2015/2/section/33/enacted

[16] The National Archives, "Domestic Abuse Act 2021",2021. Accessed on: Nov 08, 2021 [Online]. Available From: https://www.legislation.gov.uk/ukpga/2021/17/part/6/crossheading/di sclosure-of-private-sexual-photographs-and-films/enacted

[17] The National Archives, "Malicious Communications Act 1988", 1988. Accessed on: Nov 08, 2021 [Online]. Available From: https://www.legislation.gov.uk/ukpga/1988/27/section/1

[18] The National Archives, "Voyeurism (Offences) Act 2019", 2019. Accessed on: Nov 08, 2021 [Online]. Available From: https://www.legislation.gov.uk/ukpga/2019/2/section/1/enacted

[19] The National Archives, "Stalking Protection Act 2019", 2019. Accessed on: Nov 08, 2021 [Online]. Available From: https://www.legislation.gov.uk/ukpga/2019/9/contents/enacted/data.ht $\underline{\mathrm{m}}$

[20] Bournemouth University,"Cyber Security Month: Think before you click", 2018. Accessed on: Jan 10, 2022 [Online]. Available From: https://www.bournemouth.ac.uk/news/2018-10-09/cyber-securitymonth-think-you-click

[21] Bournemouth University,"Tips to reduce password related cyberattacks", 2020. Accessed on: Jan 10, 2022 [Online]. Available From: https://www.bournemouth.ac.uk/news/2020-05-14/tips-reducepassword-related-cyber-attacks

[22] Action Fraud UK. "24/7 LIVE CYBER REPORTING FOR BUSINESSES", 2022.Accessed on: Jan 10, 2022 [Online]. Available From: https://www.actionfraud.police.uk/report-phishing

[23] The Suzy Lamplugh Trust, "STALKING HELP AND ADVICE" 2019. Accessed on: Jan 10, 2022 [Online]. Available From: https://www.suzylamplugh.org/stalking-help-and-advice

[24] Cyber Civil Rights. "Online Removal Guide",2022. Accessed on: Jan 10, 2022 [Online]. Available From: https://cybercivilrights.org/online-removal/\#16401207901504483c3ca-e4be

[25] The Revenge Porn Helpline. "How can we help you?", 2022.Accessed on: Jan 10, 2022 [Online]. Available From: https://revengepornhelpline.org.uk/ 